\title{
FINANCE FOR GROWTH AND POLICY OPTIONS FOR EMERGING AND DEVELOPING ECONOMIES: THE CASE OF updates NIGERIA
}

\author{
Wumi Olayiwola ${ }^{1+}$ \\ Henry Okodua ${ }^{2}$ \\ Evans S Osabuohien ${ }^{3}$
}

\author{
${ }^{' E}$ Economic Policy Analysis Unit (EPAU), Macroeconomic Policy \\ Department, ECOWAS Commission, Abuja, Nigeria \\ ${ }^{2, s}$ Department of Economics and Development Studies, Covenant \\ University, Ota, Ogun State, Nigeria \\ (+ Corresponding author $)$
}

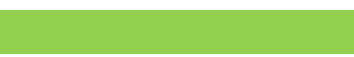

Keywords

Finance

Financial policies

Financial inclusion

Finance for growth

Growth

Emerging market economies

Nigerian economy.

\begin{abstract}
Finance is generally regarded as important for economic growth, but the role of finance in economic growth is a controversial issue in the economic literature. The concept of "finance for growth" refocuses the relationship between finance and economic growth by redirecting the role of government policies in finance, and recognizes how finance without frontiers is changing what government policies can do and achieve. The focus of this paper is not to join the debate, nor to analyse the impact of financial development on economic growth, but to discuss the concept of "finance for growth" within the context of emerging and developing economies. The increasing development needs of Emerging Market Economies (EMEs) to raise per capita income, reduce unemployment rate, construct and maintain basic infrastructure, and invest more in human capital, make the role of finance for growth in these economies indispensable. The paper reviews the financial policies in selected EMEs including: China, South Africa and Nigeria and attempts to situate the Nigerian economy among the EMEs within the context of Finance for Growth. The paper notes that financial policies designed in various EMEs had the similar goal of making the financial system to provide key financial functions. However, large differences exist in the efficiency of the financial system in each country. The paper found that what matters to economic growth is access to financial services or financial inclusion and not which sector supplies the funds. The paper suggests appropriate policy options to build confidence in the Nigerian financial system.
\end{abstract}

Contribution/ Originality: This study is one of very few studies which have investigated the concept of "finance for growth" in EMEs. It approaches the problem by assessing the performance 
of financial policies of selected EMEs in mobilizing financial resources for economic growth, and identifying policy options necessary for achieving finance for growth.

\section{INTRODUCTION}

Finance involves the transfer of funds in exchange for goods, services, or promises of future return. At a deeper level, it involves the bundle of institutions that make up an economy's financial system performing key economic functions such as: mobilizing savings; allocating capital funds (notably to finance productive investment); monitoring managers (so that the funds allocated are spent as envisaged); and transforming risk (reducing it through aggregation and enabling it to be carried by those willing to bear it).

There is no gain-saying on the fact that finance is important for economic growth, but the role of finance in economic growth is a controversial issue in the economic literature. Lucas (1988) dismisses finance as an "over-stressed" determinant of economic growth. From this perspective, finance does not cause growth, finance responds to changing demand from the real sector. The focus of this paper is not to join the debate, nor to analyze the impact of financial development on economic growth, but to discuss the concept of "finance for growth" within the context of emerging and developing economies.

The concept of "finance for growth" refocuses the relationship between finance and economic growth by redirecting the role of government policies in finance, and recognizes how finance without frontiers is changing what government policies can do and achieve. It articulates importance of legal and information base, private sector monitoring of financial sector, cost of state ownership of banks, benefits of foreign banking; and how technology is leading to finance without frontiers. The concept does support policy positions of "leaving finance to the market", "privatize the banks"; "open-up to entry of foreign financial firms and capital, but not without robust regulatory system (Caprio and Honohan, 2001; Prasad et al., 2007).

The increasing development needs of Emerging Market Economy (EME) to raise per capita income, reduce unemployment rate, construct and maintain basic infrastructure, and invest more in human capital, etc. make the role of finance for growth in these economies indispensable. The EME is loosely defined to include all countries that had embarked on economic development and reform programs, and also opened up their markets and "emerge" onto the global trading arena. The major feature of EME is the presence of vast resources (especially human and natural) that usually attract investment from foreign investors. The focus on EME is mainly due to their economic growth and the flexibility of the policies that encourages foreign investments. Typical emerging countries include Brazil, Russia, India, China, and South Africa (BRICS).

Nigeria and most other Sub-Saharan African (SSA) countries are regarded by the Vital Wave Consulting as EMEs with long-term opportunity markets. The essential characterization of this category is that they are currently the least attractive markets to multinational corporations. In addition, their economies exhibit a low standard of living with a Gross National Income (GNI) per capita under $\$ 2,000$ per year in PPP terms. Moreover, there is persistent poverty, corruption and political instability in these countries and these factors may be hampering economic growth. 
However, given consistent political and economic reforms, the long-term market opportunities make these economies very viable markets for substantial foreign investment in the long term.

There are two broad policy options that are open to EMEs to guarantee and achieve finance for growth. There is the option of domestic resource mobilization (DRM) and the other is foreign capital inflow. DRM entails the generation of savings from domestic sources and their allocation to productive investment involving public and private sectors (Quartey, 2005; Culpeper, 2008; Aryeetey, 2009). The public sector can use taxes, royalties, fines and levies, borrowing (internal and external), among others, to garner the needed financial resources. The private sector on the other hand can rely on savings from households, firms and the public to mobilize resources. In support of DRM, Culpeper (2008) argued that DRM is desirable as it can engender meaningful development, and also it may be difficult to realize development from dependence on external financial flows. However, Henri-Bernard (2010) noted that the major challenge with DRM sources from the public sector is that they are mostly based on revenues from natural resources, which are not only depleted over time but are also highly susceptible to shocks at the world market. Other factors that explain the low level of DRM include weak political governance, poor institutional quality, ethnic-religious crises, weak financial intermediation, poor insurance against adverse shocks, etc. (Fosu, 2008; Olayiwola and Osabuohien, 2010).

Foreign finance inflow comes largely in the form of portfolio investment, foreign direct investment (FDI), grants and aid, remittances, among others. Foreign financial flow is needed to fill the resource gap in capital flows hence, it is equally essential for economic development in EMEs. However, this source is not without its constraints such as the existence of limited information flow on the sovereign risks and investment opportunities in the developing countries, and long gestation period for social/infrastructural investments (Baliamoune and Chowdhury, 2003; Aizenman et al., 2007) This challenge seems to have heightened as a result of the global financial crisis that have led to a reduction in the volume of remittances inflow, official development assistance (ODA), FDI etc. in most developing countries especially those in SSA. In spite of these challenges, a growing financial sector in an economy open to international trade cannot always be insulated from cross-border financial flows (Obstfeld, 2008). EMEs may rely on a mix of the two policy options in sourcing finance for growth as it will be impracticable to depend entirely on one source.

In formulating policies to guarantee finance for growth, there will always be the need for policymakers in EMEs especially Nigeria to address the following issues: what are the major impediments to mobilizing investment funds? And what are the appropriate policies for achieving and guaranteeing finance for growth? This paper attempts to address these issues by assessing the performance of financial policies of selected EMEs in mobilising financial resources for economic growth, and identifying policy options necessary for achieving finance for growth. The rest of the paper is organised as follows. The next section discusses the basic characteristics of emerging economies (EMEs), and section 3 positions Nigeria among the EMEs within the context of finance for growth. Section 4 deals with challenges and constraints of Nigeria in achieving finance for growth, and the last section provides possible policy options. 


\section{CHARACTERISTICS OF AN EMERGING MARKET ECONOMY (EME)}

The origin of the term EME is credited to Antoine W. Van Agtmael of the International Finance Corporation of the World Bank who coined it in 1981. The basic characteristics of EME as documented in the literature are as follows:

\subsection{Economic Growth}

Emerging economies exhibit high economic growth coupled with per capita income and rapid integration into world market. There is the presence of vast resources (especially human and natural) that usually attract investment from foreign investors. They have visible economic growth and policies that encourage foreign investments. Typical emerging countries include Brazil, Russia, India, China, and South Africa (BRICS). Some of these countries also have high economic performance, rapid integration into the world market, relative political stability, friendly business environment and policy level decision governing future growth directions.

\subsection{Economic Reforms}

Emerging market economies embark on economic reform programs that makes them stronger and more responsive. They also exhibits transparency and efficiency in the capital market. EMEs also reform their exchange rate system for a stable local currency which builds confidence in an economy, especially when foreigners are considering investing. Exchange rate reforms also reduce the desire for local investors to send their capital abroad (capital flight).

\subsection{Increase in FDI}

Another key characteristic of the EMEs is the increase in both domestic and foreign investment flows. A growth in investment indicates that the country has been able to build confidence in the domestic economy. Moreover, foreign investment is a signal that the world has begun to take notice of the emerging market. When international capital flows are directed toward an EME, the injection of foreign currency into the local economy adds volume to the country's stock market and long-term investment to the infrastructure.

\subsection{Portfolio Investment and Risks}

EMEs offer an opportunity to investors who are looking to add some risk to their portfolios. The risk of an EME investment is higher than an investment in a developed market, and panic, speculation and knee-jerk reactions are also more common. A typical example is the 1997 Asian crisis, during which international portfolio flows into these countries actually began to reverse themselves. Also, there is issue of "the bigger the risk, the bigger the reward". For example, foreign investors in Nigerian quoted companies earned about N38.3 billion in 2010.

\subsection{Regional Leaders}

EME countries are regional leaders who are at the forefront of the industrialization and development curve in their neighborhoods. This makes them political heavy weights who determine the course of the region through their own policies. Also, these countries are on the 
cusp of change and this makes them a highly dynamic market having widely varying and fractious groups of consumers driving growth. There is the role that these emerging economies play in the overall development of the entire region. These countries such as China, Nigeria and South Africa play a crucial role in the rise to prominence of the entire sub-continent in world politics and world policy decisions.

\section{POSITIONING NIGERIA AMONG THE EME WITHIN THE CONTEXT OF FINANCE FOR GROWTH}

Within the concept of finance for growth, financial system must positively influence savings and investment before it will lead to economic growth. The system must perform five major functions: It must mobilize and pool savings; It must monitor investments and exert corporate governance after providing finance; It must facilitate the trading, diversification and management of risk; It must produce ex ante information about possible investments and allocate capital; and It must ease exchange of goods and services.

In order to position Nigeria among the EMEs in performing the financial functions, the brief description of financial policies of China, South Africa and Nigeria is followed by a comparative account of the rates of economic growth and other selected financial variables. Nigeria with population of more than 150 million has the largest economy in Africa and her GDP is larger than the remaining countries of ECOWAS region. South Africa is a dominant economy of the SACU region, and China remains the emerging economic power in the world.

\section{(a) A Review of Financial Policies in China, South Africa and Nigeria China}

The abandonment of the single-banking system in 1979 marked the beginning of China's financial reforms. The Agriculture Bank of China, the People's Construction Bank of China and the Bank of China were split from the People's Bank of China, which formally became the country's Central Bank. Each of the three specialized banks was to provide services to a designated sector of the economy, and the Industrial and Commercial Bank of China was created in 1984. According to China Banking Regulatory Commission (CBRC), the total asset of China banking industry was US $\$ 5.45$ trillion in 2006. The banking sector is heavily concentrated around the big four State Owned Banks (SOBs) which represent 60-70 percent of the domestic banking business. There were also 120 commercial banks, whose equity ownership is distributed among state and private investors. Credit cooperatives had $5 \%$ of domestic banking business, and foreign banks accounted for only $2 \%$ of total banking sector assets. The non-bank financial institutions accounted for $1 \%$ of total banking assets.

In 1985, the restrictions limiting each SOBs to its own designated sector were lifted and the four banks were allowed to compete with one another in providing loans and deposit services. Competition remained limited until the mid-1990s as the banks continued to serve as "policy lending conduits" for the government, and lacking the requisite autonomy to compete (Wong and Wong, 2001). The central bank law and the commercial bank law in 1995 further deepened China's financial reforms. It allowed the rest SOBs to concentrate on commercially-oriented 
lending and emphasized the need for financial institutions to incorporate commercial criteria into their lending practices. Both laws lay the basis for building a modern banking system in China. A number of non-state owned banks entered the financial system, and licenses were granted to foreign banks. There was reduction in government intervention in credit allocation, interest rate control was loosened, and standard accounting and prudential norms were recorded (Shirai, 2002). The financial reform programme also rehabilitated the balance sheet of four largest SOBs, as large scale non-performing loans (NPL) in China banking sector continue to impede the development of financial intermediaries. These problems were partly dealt with by the four asset management corporations established in 1999 with the objective of taking over a large fraction of NPL and bad debts from the SOBs. A further impulse for changes in the banking sector in China came about with China entry into the WTO in 2001.

China emerging capital markets also experienced significant development. In early 1990s, Shangai and Shenzhen Stock Exchanges were established. There was enactment and implementation of the securities Law in 1999. This law provides detailed rules and legal basis to regulate the investors and the listed companies. China stock market has played important roles by facilitating capital raising, promoting domestic investment and improving efficiency of financial resource allocation. There were rapid developments in China's bond market, money market, foreign exchange market and other aspects of financial sector.

\section{South Africa}

South Africa is Africa's second biggest economy and has embarked on wide-ranging financial reforms both in the banking sector and stock market system. Commercial banks in South Africa are the dominant segment of the financial sector with assets of about $120 \%$ of GDP. The four biggest banks- the Amalgamated Bank of South Africa (ABSA), First Rand Bank, Ned Bank, and Standard Bank-account for $85 \%$ of the total assets and have an international presence in many countries. The South African financial sector is also open to foreign financial institution.

Financial Services Board was established in 1994, with responsibility of effective supervision of non-banking financial institutions. In the same year, the first corporate governance rules were published by the King Commission and the National Payment Act of 1988 was introduced in order to bring South Africa financial settlement in line with international practice. Financial regulators and supervisors began to meet regularly and core principles of supervision of banks were developed and adopted. Application of capital-adequacy measures and effective management control system were increasingly accepted. South Africa has a sophisticated financial structure with a large and active stock exchange. The South African Reserve Bank (SARB) performs all central banking functions. The SARB is independent and operates in much the same way as Western central banks, influencing interest rates and controlling liquidity through its interest rates on funds provided to private sector banks. Quantitative credit controls and administrative control of deposit and lending rates largely disappeared. South African banks adhere to the Bank of International Standards core standards.

South Africa financial system was ranked $25^{\text {th }}$ in the world in 2008 by World Economic Forum. The various reforms have led South Africa to be included in the major global stock 
market indices. The International Monetary Fund-IMF (2008) confirms that South Africa is "fundamentally sound" with a good legal framework and sound financial infrastructure supported by prudent macroeconomic management. There is also an acknowledgement that the Johannesburg Stock Market is the fourth largest among the emerging markets and $17^{\text {th }}$ in the world in terms of total market capitalization.

\section{Nigeria}

In the 1970s, the Nigerian financial policies were dominated by policies of financial repression and indigenization. The repression policies included interest rate control, selective credit guidelines and fixed exchange rate regime. The indigenization policy was directed at nationalizing all foreign owned banks in Nigeria. The adoption of Structural Adjustment Programme (SAP) in 1986 significantly influenced various indices of the Nigerian financial system such as interest rate structure, institutional development, reorganization of money and capital markets operation, and non-deposit taking investment houses. There was deregulation of interest rates in 1987, and conditions for licensing new banks were relaxed which led to a phenomenal increase in the number of established banks in the country.

In 1988, Nigerian Deposit Insurance Corporation (NDIC) was established with the aim of providing safety and boosting public confidence in the banking system. In 1992, government owned banks were privatized and equity interest in eight commercial banks and six merchant banks were offered for sale. In July, 2004, 13-point banking programme was enunciated, which included the requirement for Nigerian banks to increase their shareholders funds to minimum of N25 billion (about 200 million dollars) by the end of 2005, phased withdrawal of public sector funds; consolidation of banking institutions through merger and acquisition, and adoption of a risk-focused and rule-based regulatory framework. The consolidation of the banking industry, however, necessitated a review of the existing code for the Nigerian Banks. The 2006 Code of Corporate Governance for Banks in Nigeria Post-Consolidation was developed to compliment other policies and enhance their effectiveness for the Nigerian banking industry. Compliance with the provisions of this Code is mandatory (Olayiwola, 2010).

As at 2009, the financial institution in Nigeria comprised of the Central Bank of Nigeria (CBN), NDIC, Securities and Exchange Commission(SEC), National Insurance Commission (NAICOM), National Pension Commission (PENCOM), 24 deposit money banks, five discount houses, 910 microfinance banks,110 finance companies, 1601 Bureaux-de-change, 1 commodity exchange, 99 primary mortgage institutions, 5 development finance institutions and 73 insurance companies. In terms of social security fund, government also introduced relevant programs of which one of them is the mandatory individual accounts within the management of the National Pension Commission (PENCOM). The program covers all the federal public-sector employees including those in military of which sources of funds are 7.5 per cent of gross salary for all employees; 2.5 per cent of gross salary for military personnel.

In 1995, capital market was liberalized with the abrogation of laws that prevent foreign investors the same right, privileges and opportunities for investment in securities in the Nigerian capital market. The Central Security Clearing System (CSCS), which is the central depository for 
all the share certificates of quoted securities, commenced operations in April, 1997. The Investment Protection Fund (IPF) was approved, and NSE launched products like mortgagebacked securities, asset-backed securities, derivatives and exchange-traded funds in 2007.

Despite of all these reforms, there is what we can call "8 year cycle" of banking crises in Nigeria. These crises have eroded the confidence in the Nigerian banking sector to perform their statutory functions. The CBN has been involved in serious reforms of these banks through the replacement of the Chief Executive Officers/Executive Directors of some banks identified as the source of instability in the industry. Also, the prime bank injected the sum of N620 billion as liquidity support for the ailing banks. All these efforts were designed to ensure a diversified, strong and reliable banking sector, and to ensure the safety of depositors' money. The reforms also aim at strengthen the banking sector so that it can play active developmental roles and become competent and competitive players in both the African and global financial systems.

\section{(B) Positioning Nigeria in the Context of Finance for Growth}

A characteristic feature of the financial system of China, South Africa and Nigeria is the dominance of banking sector and capital market as the principal institutions of mobilizing savings and source of finance. The financial policies are very dynamic and they change in response to various domestic challenges and various developments at the global financial market. Until reforms were initiated in the late 1990s, there was the prevalence of administered domestic and lending interest rates and directed credit programme. All selected EME countries liberalized their financial markets in order to provide opportunities for both domestic and foreign investors to actively participate in their markets, which in turn increased the level of liquidity, savings and growth of their economies.

To position Nigeria on "how well" its financial policy has performed with respect to financial functions, a comparison of economic growth and indicators of financial flows (covering both domestic and foreign) of these selected EMEs are conducted. For the domestic financial flow, we used the stock market capitalization as percentage of GDP $\left(m k \_g d p\right)$ and bank credit to the private sector as percentage of GDP $\left(d c b a n k \_g d p\right)$. In terms of foreign financial flow, net foreign direct investment flow as percentage of GDP $\left(f d i \_g d p\right)$ and inflow of remittance as a percentage of GDP (remit_gdp) are used.

\section{(I) Finance-Growth Nexus}

In the period of 1990 to 1999 , Nigeria and China witnessed a positive economic growth, but South Africa recorded positive growth only in 1993 to 1999. While China economic growth increased from $3.8 \%$ in 1990 to $7.6 \%$ in 1999 , Nigeria economic growth witnessed a decline from $8.2 \%$ to $1.1 \%$ during the same period. South Africa economic growth shows a similar pattern like that of China as the rate of economic growth moved from $-0.32 \%$ in 1990 to $2.36 \%$ in 1999 .

The period of 2000 to 2008 can be regarded as period of prosperity as all the selected countries witnessed positive economic growth. During this period, economic growth in Nigeria increased from $5.4 \%$ in 2000 to $10.6 \%$ in 2004 and $6 \%$ in 2008 . There were similar patterns in 
China and South Africa as their respective economic growth increased from $8.4 \%$ and $4.1 \%$ to $13 \%$ and $5.1 \%$ in 2007 (see Table 1).

Table-1. Economic Growth and Market Capitalization \% of GDP of Nigeria, China and South Africa

\begin{tabular}{c|c|c|c|c|c|c|c}
\hline & \multicolumn{3}{|c|}{ Economic growth (\%) } & & \multicolumn{3}{c}{ Market Capitalisation \% GDP } \\
\hline Year & Nigeria & China & South Africa & year & Nigeria & China & South Africa \\
\hline 1990 & 8.20 & 3.80 & -0.32 & 1990 & 4.81 & n.a. & 123.20 \\
\hline 1991 & 4.76 & 9.20 & -1.02 & 1991 & 6.88 & 0.53 & 139.74 \\
\hline 1992 & 2.92 & 14.20 & -2.14 & 1992 & 3.73 & 4.33 & 79.69 \\
\hline 1993 & 2.20 & 14.00 & 1.23 & 1993 & 4.82 & 9.22 & 131.90 \\
\hline 1994 & 0.10 & 13.10 & 3.23 & 1994 & 11.45 & 7.78 & 166.45 \\
\hline 1995 & 2.50 & 10.90 & 3.12 & 1995 & 7.23 & 5.78 & 185.64 \\
\hline 1996 & 4.30 & 10.00 & 4.31 & 1996 & 10.09 & 13.29 & 168.07 \\
\hline 1997 & 2.70 & 9.30 & 2.65 & 1997 & 10.06 & 21.66 & 155.95 \\
\hline 1998 & 1.88 & 7.80 & 0.52 & 1998 & 8.98 & 22.69 & 126.77 \\
\hline 1999 & 1.10 & 7.60 & 2.36 & 1999 & 8.45 & 30.53 & 197.08 \\
\hline 2000 & 5.40 & 8.40 & 4.15 & 2000 & 9.21 & 48.48 & 154.24 \\
\hline 2001 & 3.10 & 8.30 & 2.74 & 2001 & 11.26 & 39.55 & 117.95 \\
\hline 2002 & 1.55 & 9.10 & 3.67 & 2002 & 9.71 & 31.85 & 166.51 \\
\hline 2003 & 10.30 & 10.00 & 3.12 & 2003 & 14.03 & 41.51 & 160.66 \\
\hline 2004 & 10.60 & 10.10 & 4.86 & 2004 & 16.47 & 33.12 & 210.89 \\
\hline 2005 & 5.40 & 10.40 & 4.97 & 2005 & 17.24 & 34.92 & 232.87 \\
\hline 2006 & 6.20 & 11.60 & 5.32 & 2006 & 22.35 & 91.29 & 277.43 \\
\hline 2007 & 6.45 & 13.00 & 5.10 & 2007 & 52.04 & 184.09 & 293.77 \\
\hline 2008 & 6.00 & 9.00 & 3.06 & 2008 & 24.05 & 64.56 & 177.71 \\
\hline
\end{tabular}

The economy of China had grown on a two-digit average between 2003 and 2009, in contrast to an average of below 5\% for South Africa. During the entire period, it is evident that the economic growth experienced by China was high and more relatively stable compared to Nigeria and South Africa. The basic question is what accounts for differences in economic growth experience?.

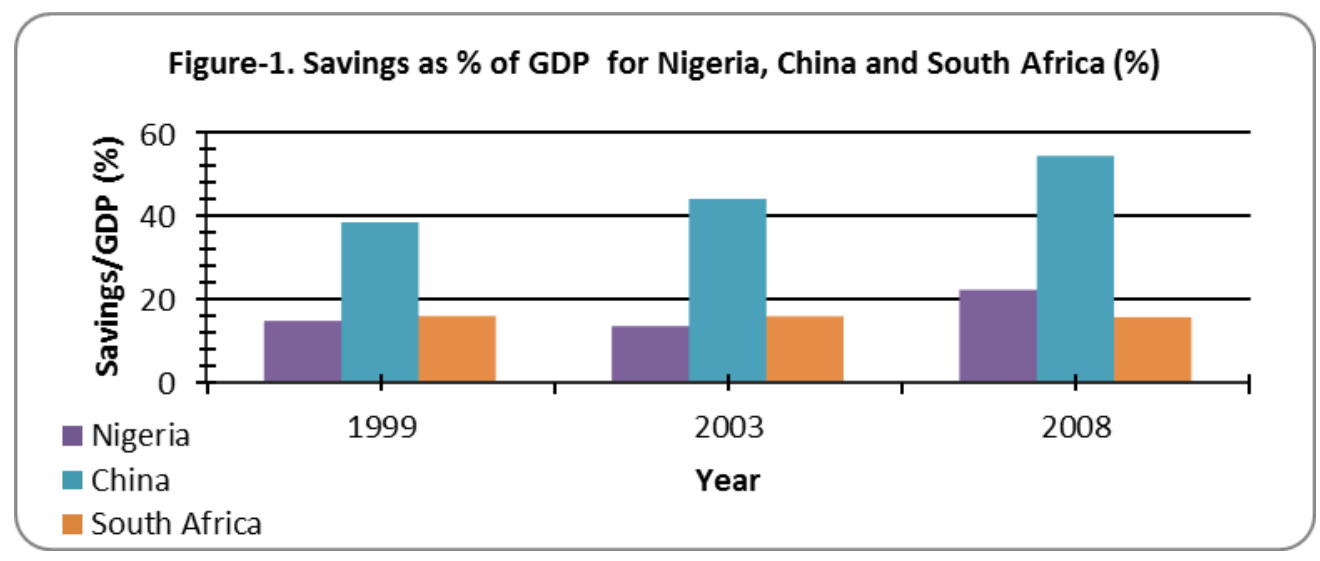

China average rate of growth of GDP for the period of 1991 to 2004 was $10.04 \%$. Prior to financial reforms in China, gross capital formation was averaged at $27.4 \%$ and this increased to $36.46 \%$ for the period of 2001 to 2008. As shown in Figure 1, the economic growth experienced 
by China is traceable to continuous increase in both savings and investment. The domestic savings rate as percentage of GDP increased from 37\% in 1999 to 52\%in 2008. Also, during the same period, the percentage of investments to GDP increased from $36 \%$ to $43 \%$ (see Figure 2).

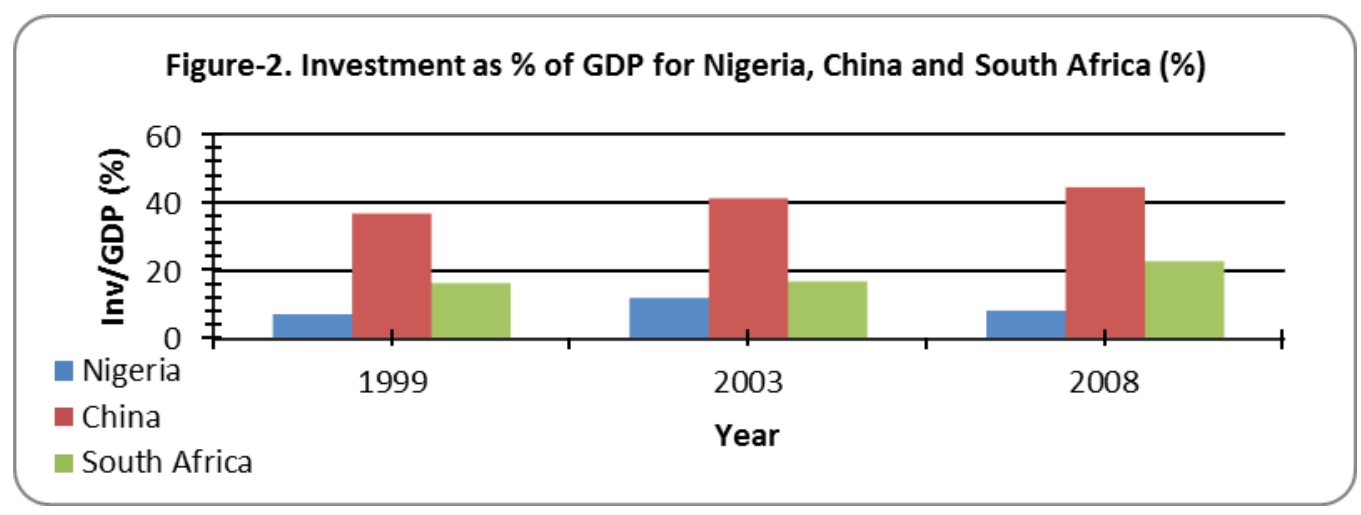

South African economic growth is driven by increase in investment, as it is observed that in the period of 1999 to 2008, gross investments was always greater than savings. The contrast is the case with Nigeria, as the increase in savings rate from $11 \%$ in 1999 to $21 \%$ in 2008 was not matched by corresponding increase in investments rate. In the period of 2003 and 2008, investments as a percentage of GDP decreased from $11 \%$ to $7 \%$ (see Table 2 )

\section{(b) Capital Market Development}

As shown in Figure 3, China that established stock exchange market in early 1990s performed better in terms of market capitalization compared to Nigeria. South Africa should be regarded as having the best stock and bond market among the selected countries. In the period of 1990 to 2000, the value of market capitalization in South Africa was more than the GDP. It increased from $123.2 \%$ in 1990 to $154.2 \%$ in year 2000 and as high as $277.4 \%$ in 2006. In the case of Nigeria, we can conclude that the country has a weakened capital market as the market capitalization as percentage of GDP was less than $10 \%$, and increased from $4.8 \%$ in 1990 to $9.2 \%$ in 2000 .

Also, on the average, Nigeria position was better compared to China in the period of 1991 to 1995 , as the indicator had an average value of less than $6 \%$ compared to Nigeria with average value of $8 \%$. The implementation of Security Law of 1979 led to a dramatic turn-around in China in the period of 2000 and 2007 as market capitalization increased from $48.9 \%$ to $184.1 \%$ respectively. Though Nigeria also recorded an improvement during the period, but it was less compared to South Africa and China. The effect of Global financial Crisis was felt in all selected countries as all of them recorded a lower market capitalization in 2008. The impact was more pronounced in China and South Africa. This is an indication that capital markets of China and South Africa are more integrated into the global economy compared to Nigeria. 


\section{Figure-3. Market capitalization as \% of GDP in China, South Africa and Nigeria}
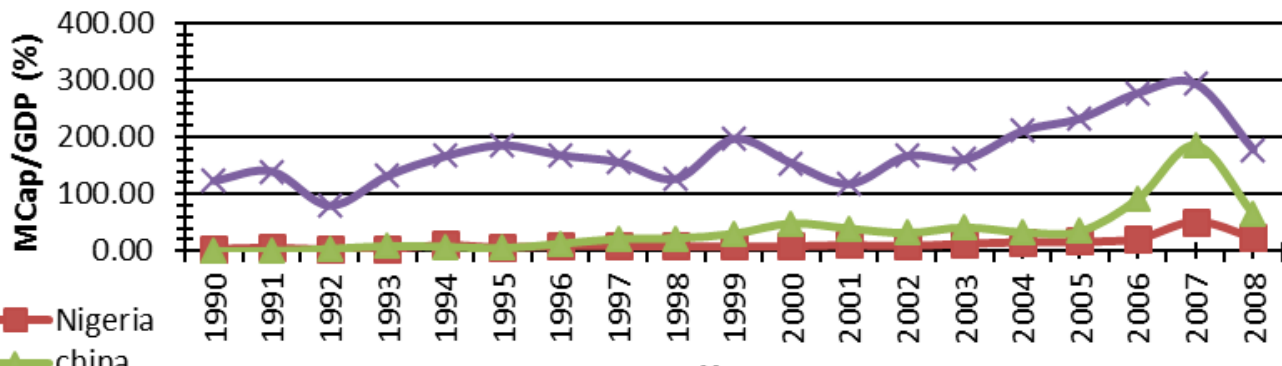

- china

$\because$ South Africa

Year

Source: Authors' Computation using data from World Development Indicators

\section{(c) Private Sector Development}

Another indicator worthy of consideration is bank credit to private sector. South Africa and China- despite being a late-comer into the market economy- had a viable private sector that has been an increasingly dynamic component of the economy and a powerful engine for economic growth. This was made possible by the rapid development of financial intermediation by continuous increase in bank credit to the private sector. As shown in Figure 4, in South Africa, for the period of 1992 to 2008, domestic bank credit as percentage of GDP had been more than 100\% ranging from almost $120 \%$ in 1992 to $172 \%$ in 2008 . In China, it increased from more than $100 \%$ in 1997 to $126 \%$ in 2008 . The contrast is the case of Nigeria as the value was less than $30 \%$ during the same period. In China and South Africa, it takes a well-developed financial sector as well as business friendly environment to channel these domestic resources into the private sector.

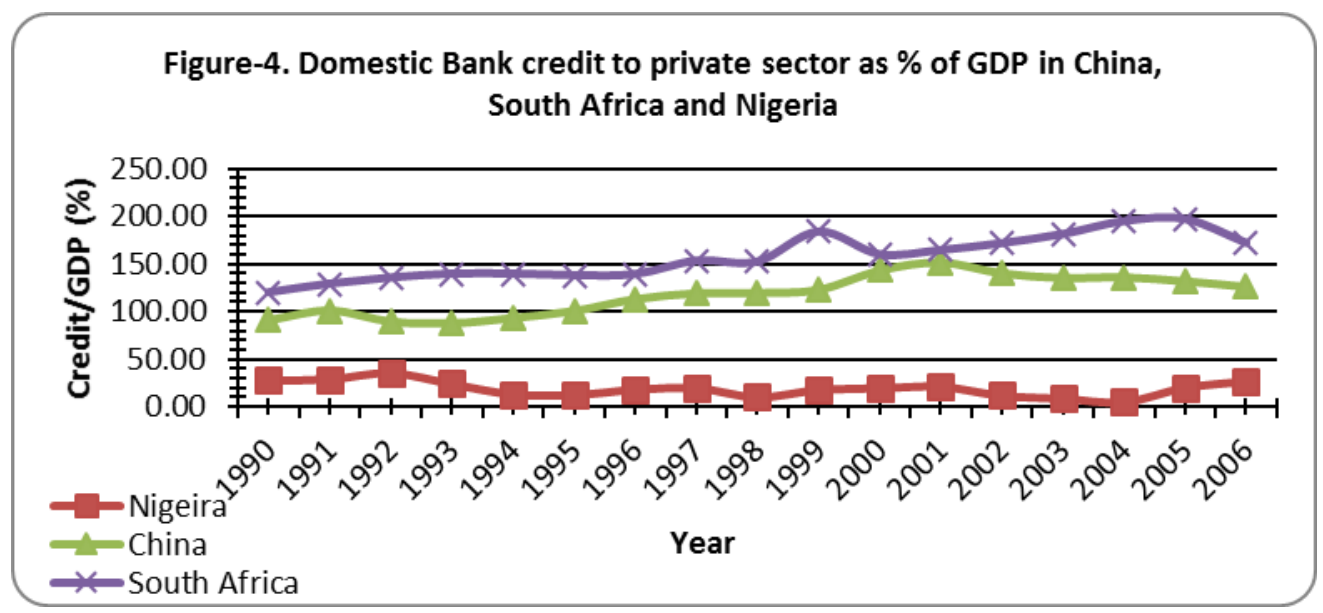

Source: Authors' Computation using data from World Development Indicators

In Nigeria, the public sector sees the banking sector as the main source of deficit financing. Among the countries considered, Nigeria has the lowest credit to the private sector. This low 
level of credits to private sector is a clear attestation to the fact that it is easier for the public sector to access bank credit compared to the private sector.

\section{(d) Foreign Financial Flow}

China was able to attain a higher rate of economic growth because it could attract quite substantial FDI. As a result of lower production costs, enormous market and preferential treatment of foreign investors, FDI in China grew from average of US $\$ 1$ billion a year to US $\$ 100$ billion annually. The FDI further leads to economic modernization, technology transfers, job creation and human capital development. The contrast is the case of Nigeria. The bulk of FDI is targeted at extractive industries especially petroleum sector. Moreover, deposit outflows accounted for more than half of total gross capital outflows (Olayiwola and Okodua, 2013). Figure 5 clearly shows that for Chinese economy, trends in FDI and economic growth exhibited similar pattern over the period, while remittance experienced consistent and gradual upward trend. This strongly suggests that FDI remains a major source of economic growth in China. Surprisingly, trends in FDI and economic growth for Nigeria did not show such similar pattern as observed for China.

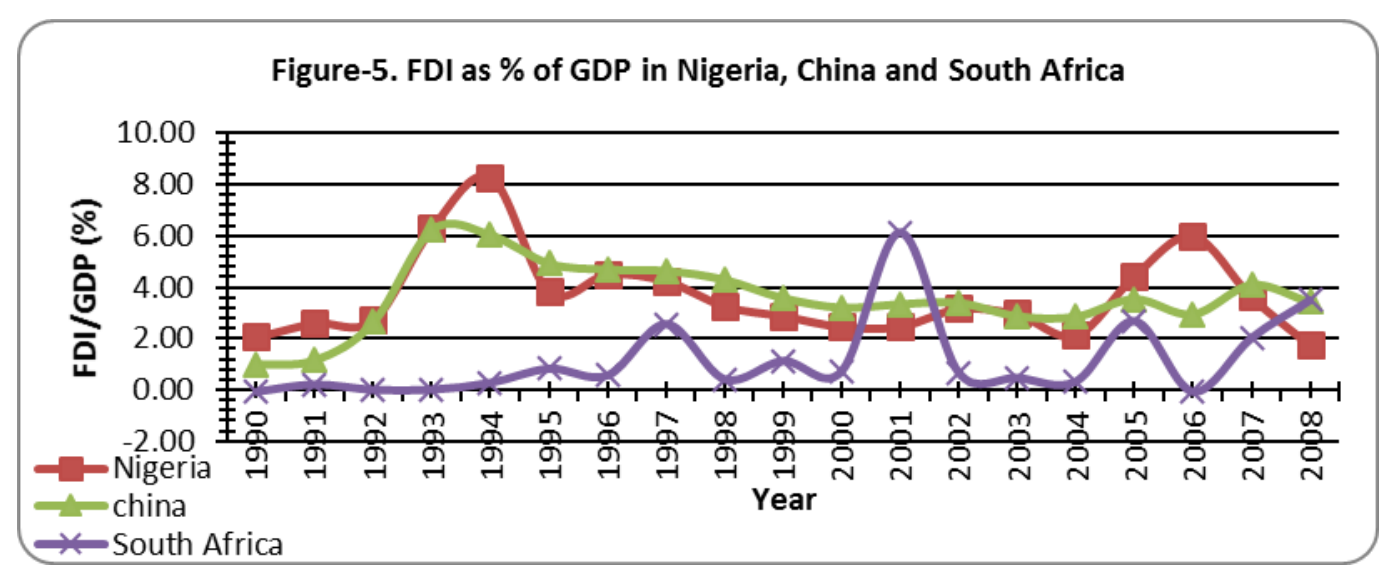

Source: Authors' Computation using data from World Development Indicators

Also, remittance is expected to be additional source of growth financing in terms of its contribution to savings and investment. Figure 6 clearly shows that Nigeria had a higher ratio of remittance to GDP among the selected EME countries. On the average, remittance to GDP ratio of South Africa and China was less than 1\%. The average value was 5\% in the period of 1990 to 2008 in Nigeria. 
Figure-6. Remittance as \% of GDP of Nigeria, China and South Africa

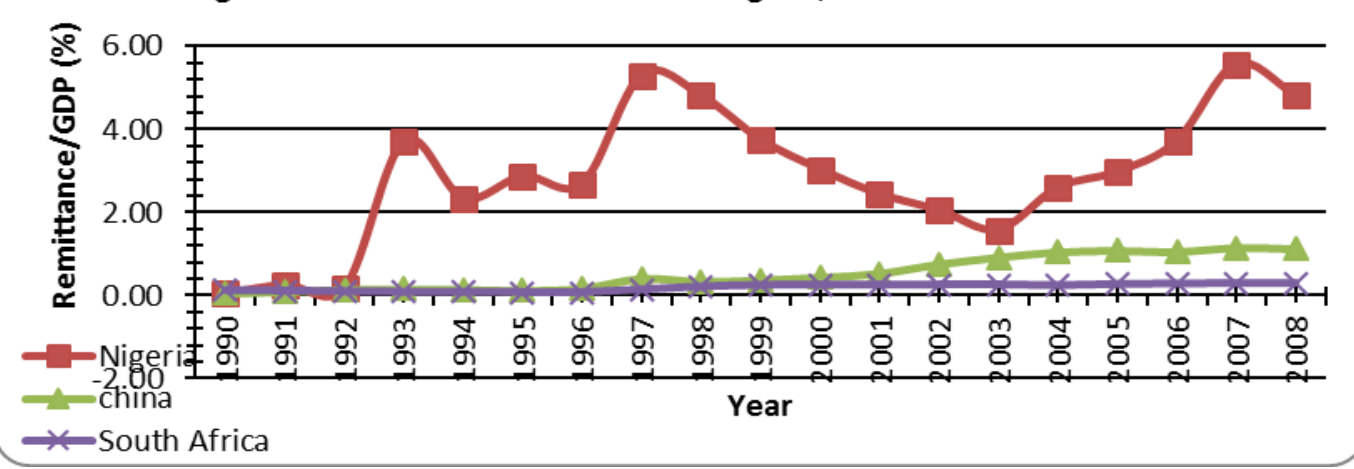

Source: Authors' Computation using data from World Development Indicators

The growth impact of remittance is however questionable as the real impact cannot be understood, nor government policies have any control on its destination and use. Even, market forces are unable to channel the resources to the most productive sectors.

\section{CHALLENGES AND CONSTRAINTS OF NIGERIA IN THE CONTEXT OF FINANCE FOR GROWTH}

From the previous section, the basic question to ask is why has Nigeria had poor performance compared to other selected EME countries in nearly all indicators of finance-growth nexus?

\section{(a) The Financial System}

Financial system encompasses two major concepts: financial market (such as bonds, stocks and foreign exchange) and financial institutions (banks, insurance companies, mutual funds etc). Since 1999 and to date, the financial system of Nigeria has experienced a great deal of transformation both in the number, quality and varying degrees of services it provide. However, the positive impact from such transformation in the development of the real sector of the economy has not been really actualized. This can be attributed to the practice amongst operators that placed their individual corporate interest higher than the larger economy. The major challenge of Nigerian financial system is the issue relating to enforcement of corporate governance principles.

A review of the legislation relating to corporate governance in the banking sector and the analysis of the standard of corporate governance in Nigeria clearly show a divergence between the code of corporate governance and its compliance (Olayiwola, 2010). This divergence therefore raises many issues. Institutions and the legal framework for effective corporate governance appear to be in existence. Compliance and enforcement appear to be weak or nonexistent.

The systemic distress in the sector and unpleasant consequences on all shareholders therefore call for certain imperatives of good corporate governance. An assessment of the health of deposit money banks in 2009, shows that 11 of them were exhibiting serious weaknesses in the sense that they were unable to meet the stipulated minimum of 10.0 per cent Capital Adequacy Ratio (CAR). Also, the assets quality of these 11 banks, measured as the ratio of non-performing loans to industry total, deteriorated by 26.5 percentage points to 32.8 per cent between 2008 and 2009 , 
this is higher than the 20.0 per cent international threshold and the maximum prescribed by the Contingency Plan for Systemic Distress (Central Bank of Nigeria-CBN (Various Issues), 2009).

Apart from this, the performance of the sector in terms of its contribution to value added show that the sector dropped from 1.69 per cent in 2006 to 1.56 per cent in 2008 but increased to 1.74 per cent in 2009. The present condition of the financial system in Nigeria is far from ideal, and achieving the goals may seem impossibly distant. Government interventions were taking place in the presence of weak professional capacity and large amount of doubtful loans.

Table 2 clearly shows that Nigeria has the highest bank capital to assets ratio among the selected countries in the period of 2002 to 2008 ranging from $10.7 \%$ to $18 \%$. The worrisome part is the bank non-performing loans. It was as high as 22.6 and $21.6 \%$ in 2000 and 2004 respectively. South Africa had a value of less than $4 \%$ during the same period. Various CBN reforms are however yielding positive results as there was a meaningful decline to $6.3 \%$ in 2008 .

Table-2. Bank Non-Performing Loans to Total Gross Loans in Nigeria

\begin{tabular}{c|c|c|c|c|c|c|c}
\hline \multicolumn{4}{c|}{ Bank capital to assets ratio (\%) } & \multicolumn{3}{c}{ Bank non-performing loans to total gross loans (\%) } \\
\hline Year & Nigeria & China & South Africa & Year & Nigeria & China & South Africa \\
\hline 2000 & 7.4 & n.a & 8.7 & 2000 & 22.6 & 22.4 & n.a \\
\hline 2001 & 7.5 & 4.1 & 7.8 & 2001 & 19.7 & 29.8 & 3.1 \\
\hline 2002 & 10.7 & n.a & 9.3 & 2002 & 21.4 & 26.0 & 2.8 \\
\hline 2003 & 9.6 & 3.8 & 8.0 & 2003 & 20.5 & 20.4 & 2.4 \\
\hline 2004 & 9.9 & 4.0 & 8.2 & 2004 & 21.6 & 13.2 & 1.8 \\
\hline 2005 & 12.4 & 4.4 & 7.9 & 2005 & 18.1 & 8.6 & 1.5 \\
\hline 2006 & 14.7 & 5.1 & 7.9 & 2006 & 8.8 & 7.1 & 1.1 \\
\hline 2007 & 16.3 & 5.8 & 7.9 & 2007 & 8.4 & 6.2 & 1.4 \\
\hline 2008 & 18.0 & 6.1 & n.a & 2008 & 6.3 & 2.4 & 3.9 \\
\hline
\end{tabular}

\section{(b) Financial Market}

Table 3 also shows that Nigeria financial market lacks the liquidity needed for a sustainable bond market that can fund growth and development in the public and private sectors. In this table, the proportion of market capitalization (MK) to GDP fell from 52.04 per cent in 2007 to 20.18 per cent in 2009.

Table-3. Proportions of Market Capitalization (MK), Financial and Insurance Sectors to GDP, 1999-2009

\begin{tabular}{c|c|c|c|c}
\hline Year & MK (N'Billion) & Financial Sector/GDP (\%) & Insurance/GDP (\%) & MK/GDP (\%) \\
\hline 1999 & 0.00 & 1.36 & 0.04 & 8.45 \\
\hline 2000 & 0.00 & 1.06 & 0.03 & 9.21 \\
\hline 2001 & 0.00 & 1.26 & 0.04 & 11.26 \\
\hline 2002 & 0.00 & 1.23 & 0.04 & 9.71 \\
\hline 2003 & 0.00 & 1.05 & 0.03 & 14.03 \\
\hline 2004 & 1.93 & 0.99 & 0.03 & 16.47 \\
\hline 2005 & 2.90 & 0.98 & 0.03 & 17.24 \\
\hline 2006 & 5.12 & 1.69 & 0.05 & 22.35 \\
\hline 2007 & 10.19 & 1.60 & 0.05 & 52.04 \\
\hline 2008 & 6.45 & 1.56 & 0.05 & 24.05 \\
\hline 2009 & 4.26 & 1.74 & 0.05 & 20.18 \\
\hline
\end{tabular}

It is also obvious that Nigeria lacks non-banking financial services, such as securities market and insurance. The contribution of non-banking financial sector to GDP was less than $2 \%$ in the 
period of 1999 to 2009. The sector seems too poor and small to sustain a liquid securities market on its own.

\section{(c) Financial Intermediation}

Why is this channeling of funds from savers to spenders so important to the economy? The answer is that the people who save are frequently not the same people who have profitable investment opportunities available to them, the entrepreneurs. Without financial markets, it is hard to transfer funds from a person who has no investment opportunities to one who has.

The average savings-GDP ratio in Nigeria was less than $30 \%$ compared to $48 \%$ in China and $43 \%$ in South Africa in the period of 1999 to 2009. Apart from low savings, another major challenge is financial intermediation which is a good measure of ability of the country of converting savings to investment. Here, we use the savings-investment gap to measure this challenge. In the period of 1999 to 2009, investment to GDP ratio was less than savings-GDP ratio as can be seen in Table 4 .

Table-4. Savings and Investment in Nigeria (Naira Billion)

\begin{tabular}{c|c|c|c|c|c|c}
\hline Year & Economic Growth (\%) & & S-I gap & S/GDP (\%) & I/GDP (\%) & \\
\hline 1999 & 1.10 & & 50.63 & 14.73 & 7.27 & \\
\hline 2000 & 5.40 & & 79.36 & 35.42 & 7.31 & \\
\hline 2001 & 3.10 & & 35.91 & 11.23 & 7.20 & \\
\hline 2002 & 1.55 & & 40.89 & 15.52 & 9.18 & \\
\hline 2003 & 10.30 & & 10.43 & 13.48 & 12.07 & \\
\hline 2004 & 10.60 & & 62.78 & 20.34 & 7.57 & \\
\hline 2005 & 5.40 & 74.82 & 21.96 & 5.53 & \\
\hline 2006 & 6.20 & 67.69 & 25.81 & 8.34 & \\
\hline 2007 & 6.45 & & 61.62 & 24.18 & 9.28 & \\
\hline 2008 & 6.00 & & 62.32 & 22.20 & 8.36 & \\
\hline 2009 & 7.00 & & 60.53 & 25.06 & 9.89 & \\
\hline
\end{tabular}

Sources: CBN Annual Reports and Financial Statements; World Development Indicators

The positive value of savings-investment gap is a clear indication that savings mobilized are not channeled to investment. The gap was more than 50\% for the period 1999 to 2009 except between 2001 and 2003. In effect, it was as huge as N79.36 billion in 2000 and N74.82 billion in 2005 (Table 4). This suggests the existence of sizeable unutilized domestic resources for productive purposes. The basic question here is why is there the presence of wide savingsinvestments gap in Nigeria?

Figure 7 provides answer to the question. Among the selected EME countries, Nigeria had the highest lending rate ranging from $25.3 \%$ in 1990 to $15.48 \%$ in 2008. In the period of 1999 to 2008, when the average lending rate was about $6 \%$ in China, it was closely to $20 \%$ in Nigeria. In essence, the cost of borrowing in Nigeria is too high. With low borrowings by firms from banks, the borrowing cost depends on the operational efficiency and competitiveness of the banking market. In this respect, the performance of Nigeria falls behind, as financial reform has been associated not only with higher lending interest rates, but also with a widening of intermediation spreads - at least partly reflecting increased exercise of market power by banks. 


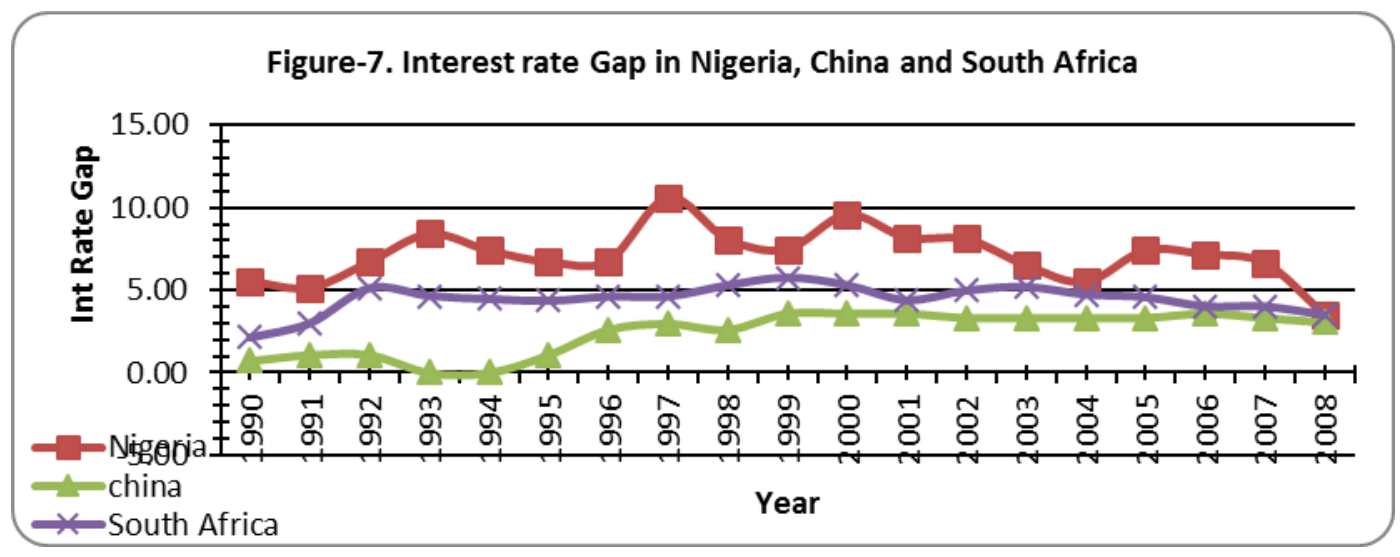

Source: Authors' Computation using data from World Development Indicators

\section{(d) Fiscal Federalism in Nigeria}

Another major challenge worthy of mentioning is fiscal federalism as practiced in Nigeria. As documented in Table 5, the Federal Government exercises legislative control on about $71.1 \%$ of tax base in Nigeria (15 out of 21), the State Government has control on about 28.57\% (6 out 21), while the Local Government has no control. The State Government is responsible for the administration and collection of $50 \%$ (11 out of 21 ) while local governments are responsible for administering and collecting only $9.52 \%$ (2 out 21 ).

Table-5. The Structure of Tax System in Nigeria

\begin{tabular}{c|c|c}
\hline \multirow{2}{*}{ Number of Taxes } & \multicolumn{2}{|c}{ Jurisdiction } \\
\cline { 2 - 3 } & Legislation & Administration and Collection \\
\hline Federal Government & 15 & 8 \\
\hline State Government & 6 & 11 \\
\hline Local Government & 0 & 2 \\
\hline Total & 21 & 21 \\
\hline
\end{tabular}

Sources: (Development Policy Centre-DPC, 1998; FIRS-Federal Inland Revenue Services, 2008; Olayiwola and Osabuohien, 2010)

This kind of fiscal structure is termed Fiscal Hydrocephalus (Olayiwola and Osabuohien, 2010). Hydrocephalus is a medical condition where the head gets very big while the limbs and the rest of the body become very stunted usually arising from the accumulation of excess fluids in the brain and is known to result in serious mental retardation with a high risk of paralysis and even death (Development Policy Centre-DPC, 1998; Olayiwola and Osabuohien, 2010). The fiscal structure in Nigeria favors over-concentration of resources at the federal government level to the detriment of both the state and local governments. This deprivation of necessary resources at the lower levels of government creates a situation of "stunted body and limbs" in the economy. Due to the limited capacity of states to generate domestic resources to finance their expenditure, nearly all states in Nigeria "run" to money and capital market to source fund. In the process, they deprive the private sector easy access to the limited available resources. 


\section{POLICY OPTIONS AND CONCLUSION}

The analysis has clearly shown that finance is important for a sustainable growth. It also shows that financial policies designed in various EME countries had the main aim of making the financial system to provide financial functions. However, there are large differences in how well the financial system in each country provided these functions. Also, it is well noted that what matters to economic growth is access to financial services and not who supplies them, whether it is private sector as in South Africa and Nigeria or the combination of public and private sectors as in China.

The financial policy in Nigeria has not been able to achieve the desired result in providing financial services. The country has not experienced a remarkable economic growth like other EMEs. It has very weak money and capital markets that can perform the role of mobilizing savings and financial intermediation. The private sector is weak and there is an unhealthy competition between the private and public sectors in terms of access to bank credits. The country fails in attracting appropriate FDI and shows a remarkable performance in terms of remittance that is very difficult to channel to investment ventures. All these challenges are attributed to weak and unstable banking system, poor and small financial market, high lending rate coupled with wide interest rate gap and fiscal misalignment of the public sector.

As an emerging economy, Nigeria should take the advantages of accompanied potential benefits of an emerging market by mitigating major constraints to financial sector development and create conducive atmosphere for inflows of foreign capital. The financial market is too small to afford a closed financial system with exclusively "domestic" banks and other intermediaries. Foreign banks will be needed to complement domestic banks in rendering financial services. The country is too small to do without the benefits of access to global finance, including accessing financial services from foreign or foreign-owned financial firms.

Appropriate policy option must build confidence in the financial system as well as enhancing financial intermediary.

1. Monitoring of banks and exerting corporate governance is very essential. Corporate governance is central to understanding economic growth in general and role of financial factors in particular. In the spirit of corporate governance, the CBN must overcome the challenge associated with problems of information asymmetry. The complexity of modern economic and business activity has greatly increased the variety of ways in which insiders try to conceal banks' performance. Although progress in technology, accounting, and legal practice has improved the tools of detection, the balance of the asymmetry of information between users and providers of funds has not been reduced in Nigeria. Legal infrastructure may need upgrading, and judicial enforcement is the most relevant. Where the rule of law is weak, the financial sector cannot be expected to function well.

2. Policy should be directed at helping the Nigerian economy to absorb bank credit in the real sector so as to translate these flows of domestic resources into economic growth. The authorities need to be aiming to remove barriers that prevent borrowers and lenders 
from accessing money and capital markets such as high lending rate and stringent conditions attached to accessing bank credits

3. Government ownership of banking should be discouraged as there is clear evidence that the goals of such ownership are rarely achieved in Nigeria. It weakens the financial system rather than the contrary. Central bank intervention in the ownership of banks should be limited to the crisis period. Drawing on public funds to recapitalize some banks may be unavoidable in truly systemic crises, but they must be used sparingly to leverage private funds and incentives. Procrastination and half-measures bear a high price tag that will affect the financial system and the economy.

4. Exploring the possibilities of regional cooperation especially in the area of capital market development will bear a positive result. If democracy is weak and ethnic conflict high, a significant level of uncertainty will likely prevail, which will deter physical entry by good investors. E-finance or joining a regional financial system may be the best hope of getting access to higher quality financial services. The idea of ECOWAS regional capital market, ECOWAS Common Investment Market and ECOWAS Regional Monetary Cooperation are good initiatives that should be supported.

In conclusion, in an EME country like Nigeria, there is ample evidence of the importance of sound financial infrastructure in the context of finance for growth. Unregulated financial system will fail, but the wrong type of regulation is counterproductive. The right types of regulation are "incentive" and "sanctions". Incentive and sanction system should be designed with a view to ensuring that the impact they create for market participants helps to achieve their goals rather than hinder them. More specifically, the right type of regulation should: i) work with the market, but does not leave it to the market. ii) Keep authorities at arm's length from transactions, lessening the opportunities for conflicts of interest and corruption; and iii) promote prudent risktaking. In fact, the financial policy must be market-aware.

\section{REFERENCES}

Aizenman, J., B. Pinto and A. Radziwill, 2007. Sources for financing domestic capital—is foreign saving a viable option for developing countries? Journal of International Money and Finance, 26(5): 682702.

Aryeetey, E., 2009. The global financial crisis and domestic resource mobilization in Africa. Mimeo, ISSER.

Baliamoune, M. and R. Chowdhury, 2003. The long-run behavior and short-run dynamics of private savings in Morocco. Savings and Development, 27(2): 135-160.

Caprio, G. and P. Honohan, 2001. Finance for growth: Policy choices in a volatile World' MPRA Paper No. 9929.

Central Bank of Nigeria-CBN (Various Issues), 2009. Annual reports and financial statements. Abuja: CBN.

Culpeper, R., 2008. Enhancing domestic resource mobilization. G-24 Policy Brief ,No. 25.

Development Policy Centre-DPC, 1998. Economic Intelligence, No. 7.

FIRS-Federal Inland Revenue Services, 2008. Current tax policy reforms. Available from http://www.firs.gov.ng/about_us/mission_and_mandate/index.html\#4 [Accessed 5/5/08]. 
Fosu, A.K., 2008. Democracy and growth in Africa: Implications of increasing electoral competitiveness. Economics Letters, 100(3): 442-444.

Henri-Bernard, S.L., 2010. Taxation for development in Africa: A shared responsibility. Trade Negotiations Insights, 9(6): 3-4.

International Monetary Fund-IMF, 2008. South Africa: Financial stability assessment. Publication Services Washington DC.

Lucas, R.E., 1988. On the mechanics of economic development. Journal of Monetary Economics, 22(1): 3-42.

Obstfeld, M., 2008. International finance and growth in developing countries: What have we learned? Commission on growth and Development Working Paper No. 34, World Bank.

Olayiwola, K. and H. Okodua, 2013. Foreign direct investment, non-oil export and economic growth in Nigeria. A causality analysis. Asian Economic and Financial Review, 3(11): 1479-1496.

Olayiwola, K.W. and E.S.C. Osabuohien, 2010. Evaluation of the role of fiscal policy in promoting savings, investment and capital formation in Nigeria. The Journal of Banking and Finance, 10(1): 26-45.

Olayiwola, W.K., 2010. Practice and standard of corporate governance in the Nigerian Banking Industry. International Journal of Economics and Finance, 2(4): 178-189.

Prasad, E., R.G. Rajan and A. Subramanian, 2007. Foreign capital and economic growth. Brookings papers on economic activity. Economic Studies Program, The Brookings Institution, 38(2007-1): 153-230.

Quartey, P., 2005. Financial sector development, savings mobilization and poverty reduction in Ghana. UNU-WIDER Research Paper No. 2005/ 71.

Shirai, S., 2002. Banking sector reform in India and China: Does India experience offer lessons for China future reform agenda. JBICJ Discussion Paper Series, Discussion Paper No. 2. 